\title{
Detection of Borrelia burgdorferi s.l., Anaplasma phagocytophilum and Babesia spp. in Dermacentor reticulatus ticks found within the city of Białystok, Poland—first data
}

\author{
Anna Grochowska ${ }^{1}$ D . Justyna Dunaj ${ }^{1} \cdot$ Sławomir Pancewicz ${ }^{1}$. Piotr Czupryna ${ }^{1}$. \\ Piotr Majewski ${ }^{2}$ Mulugeta Wondim ${ }^{1}$ - Elżbieta Tryniszewska ${ }^{2}$. \\ Anna Moniuszko-Malinowska ${ }^{1}$
}

Received: 23 January 2020 / Accepted: 1 September 2021 / Published online: 15 September 2021 (C) The Author(s) 2021

\begin{abstract}
Pathogens carried by ticks pose a threat to both human and animal health across the world. Typically associated with rural landscapes, ticks appear to adapt well to life in urban recreational areas. Although Dermacentor reticulatus is commonly found across Europe, data on the prevalence of pathogens in this tick species, in an urban environment, are very limited. PCR was used to examine 368 D. reticulatus individuals collected in the Zwierzyniecki Forest Nature Reserve in Białystok, Poland. In total, $10.3 \%$ of ticks were infected, with Babesia spp. (9.2\%), Anaplasma phagocytophilum (0.8\%) and Borrelia burgdorferi sensu lato (0.3\%). Rickettsia spp., Bartonella spp., and Coxiella burnetii were not detected. Sequence analysis for Babesia-positive samples identified $79.4 \%$ of them as Babesia canis, $8.8 \%$ as Babesia microti, $5.9 \%$ as Babesia spp., $2.9 \%$ as Babesia venatorum, and $2.9 \%$ as Babesia vogeli. Results obtained in this study indicate that $D$. reticulatus ticks found within the urban premises of the study area are infected with at least three pathogens and therefore are an important factor in public health risk for tick-borne diseases.
\end{abstract}

Keywords Urban · Babesia canis $\cdot$ Babesia vogeli $\cdot$ Babesia venatorum $\cdot$ Babesia microti

\section{Introduction}

After Ixodes ricinus, Dermacentor reticulatus is the second most common tick species encountered in Europe (Didyk et al. 2017; Roczeń-Karczmarz et al. 2018; Stańczak et al. 2018). This species acts as a vector for multiple viral, bacterial and protozoan

Anna Grochowska and Justyna Dunaj have contributed equally to the manuscript.

Anna Grochowska

matosek.ania@gmail.com

1 Department of Infectious Diseases and Neuroinfections, Medical University of Białystok, Żurawia 14, 15-540 Białystok, Poland

2 Department of Microbiological Diagnostics and Infectious Immunology, Medical University of Białystok, Waszyngtona 15A, 15-269 Białystok, Poland 
pathogens (Didyk et al. 2017), such as Babesia spp., Tick-borne encephalitis virus (TBEV), Borrelia burgdorferi sensu lato, Anaplasma phagocytophilum, Rickettsia spp., Bartonella spp., Coxiella burnetii, Francisella tularensis and Francisella-like endosymbionts (Mierzejewska et al. 2015; Zając et al. 2017; Roczeń-Karczmarz et al. 2018).

Larvae and nymphs of $D$. reticulatus parasitize exclusively on various rodents, whereas adults feed on larger mammals, such as deer, horses, dogs or wild boars. Although D. reticulatus ticks rarely feed on humans (Dautel et al. 2006; Mierzejewska et al. 2015), they are still an important part of the pathogen circulation in the environment and therefore their infection rates should be investigated. Public health risk posed by $D$. reticulatus is significant, especially because of their exemplary abilities to survive and adapt to new environments, as well as their high reproduction rate. A fertilized $D$. reticulatus female lays over 7000 eggs, out of which a large number of larvae may survive (Šimo et al. 2004). Furthermore, in comparison to I. ricinus, D. reticulatus develops into subsequent stages at a faster rate and has greater temperature tolerance. Adult D. reticulatus ticks can survive for up to 4 years without a blood meal and because they feed on a wide variety of hosts, including wild and domestic mammals, they may spread over large distances while attached to them (Földvári et al. 2016).

Due to the rapidly progressing process of urbanization across the world, an increasing number of landscapes is being transformed into urban spaces. Although ticks are typically associated with rural surroundings, such as forests and meadows, it is now not uncommon to encounter them in parks, cemeteries, playgrounds or other urban green areas (Rizzoli et al. 2014; Akimov and Nebogatkin 2016). It is worth noting that although literature data regarding ticks in cities are comprehensive when it comes to $I$. ricinus, information on $D$. reticulatus in an urban environment is very scarce.

In this study, D. reticulatus ticks collected in Białystok, Poland, were tested for the presence of six tick-borne pathogens: B. burgdorferi s.l., A. phagocytophilum, Babesia spp., Rickettsia spp., C. burnetii and Bartonella spp.

\section{Materials and methods}

Questing D. reticulatus ticks were collected from the Zwierzyniecki Forest Nature Reserve in Białystok, Poland $\left(53^{\circ} 6^{\prime} 45^{\prime \prime} \mathrm{N}, 23^{\circ} 9^{\prime} 41^{\prime \prime} \mathrm{E}\right)$. The area is dominated by hornbeam, oak, pine and birch trees. It is located approximately $2 \mathrm{~km}$ from the city center and is popular among residents for recreational activities, such as hiking, biking, dog walking and jogging, among others.

The collection of ticks took place between April and October 2018. Questing ticks were sampled using the flagging method and subsequently placed separately in Eppendorf tubes. Each tick was identified to species and stage using taxonomic keys (NowakChmura 2013) and stored at $+4{ }^{\circ} \mathrm{C}$ until further DNA extraction.

\section{DNA isolation}

Each tick was crushed individually in a mortar with addition of $1.5 \mathrm{ml}$ of PBS (without $\mathrm{Ca}^{2+}$ and $\mathrm{Mg}^{2+}$ ions). Homogenate was centrifuged and $300 \mu \mathrm{l}$ of obtained supernatant was used for DNA extraction. This process was performed with spin column kits (EurX 
DNA Isolation Kit, Poland) in accordance with manufacturer's instructions. Afterwards, $100 \mu \mathrm{l}$ of obtained DNA extracts was stored at $-20{ }^{\circ} \mathrm{C}$ until further analyses.

\section{PCR amplification}

All PCR reactions were performed on the LabCycler (SensoQuest, Germany). Specimens were tested in pools, each containing five DNA extracts (15 $\mu \mathrm{l}$ of each). Afterwards, if a pool was positive, all its components were examined individually in order to establish the exact number of infected ticks.

\section{Borrelia burgdorferi s.I. PCR}

Borrelia burgdorferi s.l. PCR was performed with the B. burgdorferi PCR kit (GeneProof, Czech Republic) for in vitro diagnostics. A 120-bp fragment of the 16S rRNA gene encoding small ribosomal subunit was amplified. Final reaction mix volume of $40 \mu \mathrm{l}$ comprised of $30 \mu \mathrm{l}$ of MasterMix and $10 \mu \mathrm{l}$ of the template DNA extract. For minimization of risk of non-specific reactions and maximization of the sensitivity of procedure, 'hot start' technology was used. PCR inhibition was controlled by an internal standard in the reaction mix. Possible contamination during preparation was avoided by adding Uracil-DNA-glycosylase (UDG).

Reaction program was designed in compatibility with GeneProof instruction with own modifications and consisted of the following steps: UDG decontamination at $37{ }^{\circ} \mathrm{C}$ for $2 \mathrm{~min}$, initial denaturation at $95{ }^{\circ} \mathrm{C}$ for $10 \mathrm{~min}$, amplification for 45 cycles (denaturation at $95^{\circ} \mathrm{C}$ for $5 \mathrm{~s}$, annealing at $60{ }^{\circ} \mathrm{C}$ for $40 \mathrm{~s}$, extension at $72{ }^{\circ} \mathrm{C}$ for $20 \mathrm{~s}$ ) and final extension at $72{ }^{\circ} \mathrm{C}$ for $2 \mathrm{~min}$.

\section{Anaplasma phagocytophilum PCR}

To detect A. phagocytophilum DNA, a nested PCR was used targeting a fragment of $16 \mathrm{~S}$ rDNA gene encoding small ribosomal 16S RNA subunit. Reactions were performed with the Anaplasma PCR kit (Blirt-DNA Gdańsk, Poland), according to the manufacturer's instructions. In the first stage (PCR-OUT), the reaction mix volume of $50 \mu 1$ was obtained by mixing $2 \mu \mathrm{l}$ of template DNA isolate, $42 \mu \mathrm{l}$ of PCR-OUT MasterMix, $5 \mu \mathrm{l}$ of dNTPs and $1 \mu \mathrm{l}$ of Taq nova polymerase. First course of amplification proceeded the following PCR program: initial denaturation at $95{ }^{\circ} \mathrm{C}$ for $2 \mathrm{~min}, 40$ cycles (denaturation at $94{ }^{\circ} \mathrm{C}$ for $30 \mathrm{~s}$, annealing at $55^{\circ} \mathrm{C}$ for $30 \mathrm{~s}$, extension at $72{ }^{\circ} \mathrm{C}$ for $60 \mathrm{~s}$ ) and final extension at $72{ }^{\circ} \mathrm{C}$ for $5 \mathrm{~min}$. In the second stage (PCR-IN), $2 \mu \mathrm{l}$ of PCR product from the first reaction was mixed with $42 \mu \mathrm{l}$ of PCR-IN MasterMix, $5 \mu \mathrm{l}$ of dNTPs and $1 \mu \mathrm{l}$ of Taq nova polymerase. The course of amplification used in this stage followed the same steps as in PCR-OUT, but in 30 cycles.

\section{Babesia spp. PCR}

For detection of Babesia spp., a fragment of 18S rDNA gene was used, encoding a small ribosomal subunit, localized on conservative region V4. All steps for this reaction were constructed experimentally based on previous methods (Piccolin et al. 2006; Pichon et al. 2006). PCR was performed with Taq PCR Core Kit (Qiagen, Germany) with the use of a 
pair of highly specific primers: $18 \mathrm{~S}$ rDNA BAB-F2 sense 5'-GAC ACA GGG AGG TAG TGA CAA G-3' and 18S rDNA BAB-R2 antisense 5'-CTA AGA ATT TCA CCT CTG ACA GT-3' (Sigma-Aldrich, Germany) (Pichon et al. 2006; Katargina et al. 2011; Moniuszko-Malinowska et al. 2016; Dunaj et al. 2018).

The reaction mixture $(25 \mu \mathrm{l})$ contained $2.5 \mu \mathrm{l}$ of extracted DNA, $5 \mu \mathrm{l}$ of buffer $\times 10$ with $15 \mathrm{mM} \mathrm{MgCl}_{2}, 2 \mu \mathrm{l}$ of $25 \mathrm{mM} \mathrm{MgCl} 2,1 \mu \mathrm{l}$ of $10 \mathrm{mM}$ dNTPs, $1 \mu \mathrm{l}$ of $20 \mu \mathrm{M}$ primer sequencing (18S rDNA BAB-F2 and 18S rDNA BAB-R2) and $0.25 \mu \mathrm{l}(5 \mathrm{U} / \mu \mathrm{l})$ of thermostable Taq DNA polymerase. Amplification took place in the following steps: initial denaturation at $94{ }^{\circ} \mathrm{C}$ for $3 \mathrm{~min}, 40$ cycles (denaturation at $94{ }^{\circ} \mathrm{C}$ for $40 \mathrm{~s}$, annealing at $58{ }^{\circ} \mathrm{C}$ for $60 \mathrm{~s}$, extension at $72{ }^{\circ} \mathrm{C}$ for $60 \mathrm{~s}$ ) and final extension at $72{ }^{\circ} \mathrm{C}$ for $10 \mathrm{~min}$.

\section{Bartonella spp., C. burnetii and Rickettsia spp. PCR}

Diagnostic The Hum PCR BARTONELLA, The Hum PCR Coxiella burnetii and the Vet PCR RICKETTSIA detection kit (BioIngenTech, Chile) were used to detect Bartonella spp. C. burnetii and Rickettsia spp., respectively. Reactions were performed according to the manufacturer's instructions. Reaction mixture $(10.7 \mu \mathrm{l})$ contained $2.7 \mu \mathrm{l}$ of HumPCR Bartonella Premixture, HumPCR C. burnetii Premixture or VetPCR Rickettsia Premixture, accordingly, $6 \mu \mathrm{l}$ of free water and $2 \mu \mathrm{l}$ of either sample DNA, negative control or positive control. Additionally, internal control samples were prepared by mixing $2.7 \mu \mathrm{l}$ of Internal Control Mixture, $6 \mu \mathrm{l}$ of free water and $2 \mu \mathrm{l}$ of sample DNA. Afterwards, $8 \mu \mathrm{l}$ of mineral oil was added on the top of the mixture in each PCR tube.

Reactions were performed according to BioIngenTech instruction: initial denaturation at $94{ }^{\circ} \mathrm{C}$ for $2 \mathrm{~min}, 30$ cycles of amplification (denaturation at $94{ }^{\circ} \mathrm{C}$ for $30 \mathrm{~s}$, annealing at $57{ }^{\circ} \mathrm{C}$ for $30 \mathrm{~s}$, extension at $72{ }^{\circ} \mathrm{C}$ for $30 \mathrm{~s}$ ) and final extension at $72{ }^{\circ} \mathrm{C}$ for $5 \mathrm{~min}$.

\section{Electrophoresis}

Separation of amplification products was performed with electrophoresis $(90 \mathrm{~V}, 80 \mathrm{~min}$ for B. burgdorferi s.1.; $90 \mathrm{~V}, 60 \mathrm{~min}$ for A. phagocytophilum; $90 \mathrm{~V}, 45 \mathrm{~min}$ for Babesia spp.; $100 \mathrm{~V}, 45$ min for Rickettsia spp., Bartonella spp. and C. burnetii) on 2\% agarose gel (Sigma-Aldrich) stained with ethidium bromide ( $5 \mu \mathrm{g} / \mathrm{ml}$; Syngene, USA). UV illumination in Gel Logic System 100 (Kodak Imaging System, USA) was used to visualize the amplicons.

For B. burgdorferi s.l., positive samples showed amplification products of $120 \mathrm{bp}$ long (fragments of $16 \mathrm{~S}$ rRNA gene). Additionally, 168-bp long fragments of internal standard were detected in all samples (Moniuszko et al. 2014; Dunaj et al. 2018).

Anaplasma phagocytophilum infection was detected in case of presence of the $16 \mathrm{~S}$ rDNA gene fragments: 932 bp long in PCR-OUT and 546 bp long in PCR-IN. Absence of 932-bp long fragments in PCR-OUT did not exclude a positive result of test (Moniuszko et al. 2014; Dunaj et al. 2018). Positive results for Babesia spp. were approximately 420-bp long fragments of the 18S rDNA gene (Moniuszko-Malinowska et al. 2016).

For Bartonella spp., C. burnetii and Rickettsia spp., 140-bp long fragments of internal standard were detected in all samples. Amplification products with the length of 358, 340 and 322 bp were considered positive for Bartonella spp., C. burnetii and Rickettsia spp., respectively. 


\section{Sequencing analysis}

\section{Babesia spp. sequencing}

All samples positive for Babesia spp. 18S rRNA gene fragment amplicons were sequenced by Macrogen (Amsterdam, The Netherlands), with specific primers used previously for PCR. $5 \mu$ of Babesia spp. 18S rDNA amplicons obtained in PCR were combined with $5 \mu \mathrm{l}$ of each primer $(50 \mathrm{mM})$ and sent to Macrogen where they were sequenced from both sides. The results were later compared with sequences already deposed in the GenBank database using the BLAST server.

\section{Borrelia burgdorferi s.l. sequencing}

$5 \mu \mathrm{l}$ of $B$. burgdorferi s.1. 16S rDNA amplicons obtained in PCR were combined with BIG BOR-F1 $(5 \mu l 50 \mathrm{mM})$ and BIG BOR-R1 $(5 \mu 150 \mathrm{mM})$ and sent to Macrogen. Sequencing was performed using both sides of the DNA strand with primers $16 \mathrm{~S}$ rDNA BIG BOR-F1 and $16 \mathrm{~S}$ rDNA BIG BOR-R1 under conditions identical to those used in the original amplification. Afterwards, the sequences were compared with those deposed in the GenBank using the BLAST server.

\section{Evolutionary analysis by maximum likelihood}

The evolutionary history of the various Babesia genospecies was inferred by using the Maximum Likelihood method and the Tamura-Nei model (Tamura and Nei 1993). Initial tree(s) for the heuristic search were obtained automatically by applying Neighbor-Join and BioNJ algorithms to a matrix of pairwise distances estimated using the Tamura-Nei model, and then selecting the topology with superior log likelihood value. This analysis involved 34 nucleotide sequences. Codon positions included were $1 \mathrm{st}+2 \mathrm{nd}+3 \mathrm{rd}+\mathrm{Non}-$ coding. There were in total 358 positions in the final dataset. Evolutionary analyses were conducted in MEGA X (Kumar et al. 2018).

\section{Results}

In total, $368 D$. reticulatus were collected in the study area (221 females, 145 males, two nymphs). Overall, $10.3 \%$ of $D$. reticulatus ticks were infected $(38 / 368 ; 21$ females, 16 males, one nymph). Babesia spp. was detected in $9.2 \%$ of the examined ticks $(34 / 368 ; 20$ females, 13 males, one nymph). Anaplasma phagocytophilum was confirmed in $0.8 \%$ of the ticks (3/368; one female, two males). One male was infected with B. burgdorferi s.l. $(0.3 \% ; 1 / 368)$. Rickettsia spp., Bartonella spp. and C. burnetii were not identified in any of the examined ticks (Table 1). No coinfections were detected.

Sequencing analysis of Babesia-positive samples identified 79.4\% (27/34; 17 females, nine males, one nymph) of them as $B$. canis with homology ranging from 85.8 to $99.0 \%$. Among the remaining isolates, $8.8 \%$ were identified as $B$. microti (3/34; one female, two males) [Accession no. KP055650.1], 5.9\% as Babesia spp. (2/34; one female, one male) [KX857475.1, KJ956783.1], 2.9\% as B. venatorum (1/34; one female) [KR003829.1] and $2.9 \%$ as B. vogeli (1/34; one female) [MT821127.1] (Table S1). 
Table 1 Prevalence $(\%$; in parentheses: no. infected/ no. examined) of Borrelia burgdorferi s.1., Anaplasma phagocytophilum, Babesia spp., Rickettsia spp., Bartonella spp., and Coxiella burnetii in Dermacentor reticulatus ticks collected in Białystok, Poland

\begin{tabular}{lccr}
\hline Pathogens & \multicolumn{2}{l}{ Dermacentor reticulatus ticks } \\
\cline { 2 - 4 } & Females & Males & Nymphs \\
\hline Overall prevalence & $9.5(21 / 221)$ & $11.0(16 / 145)$ & $50(1 / 2)$ \\
B. burgdorferi s.1. & $0(0 / 221)$ & $0.7(1 / 145)$ & $0(0 / 2)$ \\
A. phagocytophilum & $0.5(1 / 221)$ & $1.4(2 / 145)$ & $0(0 / 2)$ \\
Babesia spp. & $9.0(20 / 221)$ & $8.9(13 / 145)$ & $50(1 / 2)$ \\
Rickettsia spp. & $0(0 / 221)$ & $0(0 / 145)$ & $0(0 / 2)$ \\
Bartonella spp. & $0(0 / 221)$ & $0(0 / 145)$ & $0(0 / 2)$ \\
C. burnetii & $0(0 / 221)$ & $0(0 / 145)$ & $0(0 / 2)$ \\
\hline
\end{tabular}

One sample positive for $B$. burgdorferi s.l. was sequenced and showed $98.1 \%$ homology with B. afzelii [MW301927.1].

\section{Evolutionary analysis by maximum likelihood}

The evolutionary history of the various Babesia genospecies was inferred by using the Maximum Likelihood method and the Tamura-Nei model. The Babesia spp. subpopulation was strongly structured into four genetic clusters, one of which was relatively distant from the others. Interestingly, B. canis (21) fell outside the distinguished clusters, which may suggest its primal origin outside from the sampling region. The tree with the highest log likelihood (-12665.52) is shown in Fig. 1.

\section{Discussion}

Although D. reticulatus is a commonly found tick species in Europe, literature data regarding their infection rates, especially in urban areas, are much scarcer than such data for $I$. ricinus. To the best of our knowledge, this is the first report on Babesia spp., A. phagocytophilum, C. burnetii and Rickettsia spp. prevalence in D. reticulatus ticks collected from urban landscapes in Poland.

In this study, the most prevalent pathogen identified in D. reticulatus ticks was Babesia spp. (9.2\%). Studies conducted in rural areas in Poland report noticeably lower prevalence: $4.2 \%$ in the Masovian region (central Poland) (Mierzejewska et al. 2015) and 2.5-4.5\% in Lublin province (eastern Poland) (Wójcik-Fatla et al. 2012; Zając et al. 2017). Similarly, $5.1 \%$ prevalence was reported within the city of Kyiv, Ukraine (Rogovskyy et al. 2018) and in rural landscapes of Serbia (5.7\%) (Tomanovic et al. 2013). Radzijevskaja et al. (2018) investigated adult $D$. reticulatus ticks collected from rural areas in Lithuania and Latvia, and found infection rates for Babesia spp. of 1.2 and $2.8 \%$, respectively. Studies from Germany (urban areas) and Belarus (rural areas and ticks collected from cattle) reported 0-0.3\% Babesia spp. infection rate (Silaghi et al. 2012, 2020; Reye et al. 2013).

Sequencing analysis of Babesia-positive samples identified the majority of isolates as B. canis, of which D. reticulatus is a known vector (René-Martellet et al. 2015; Sprong et al. 2019). In relation to the total number of ticks tested, in this study B. canis accounted for $6.8 \%$ (25/368). Other studies report infection rates ranging from 0.63 to $4.8 \%$ (Mierzejewska et al. 2015; Zając et al. 2017; Radzijevskaja et al. 2018; Rogovskyy et al. 


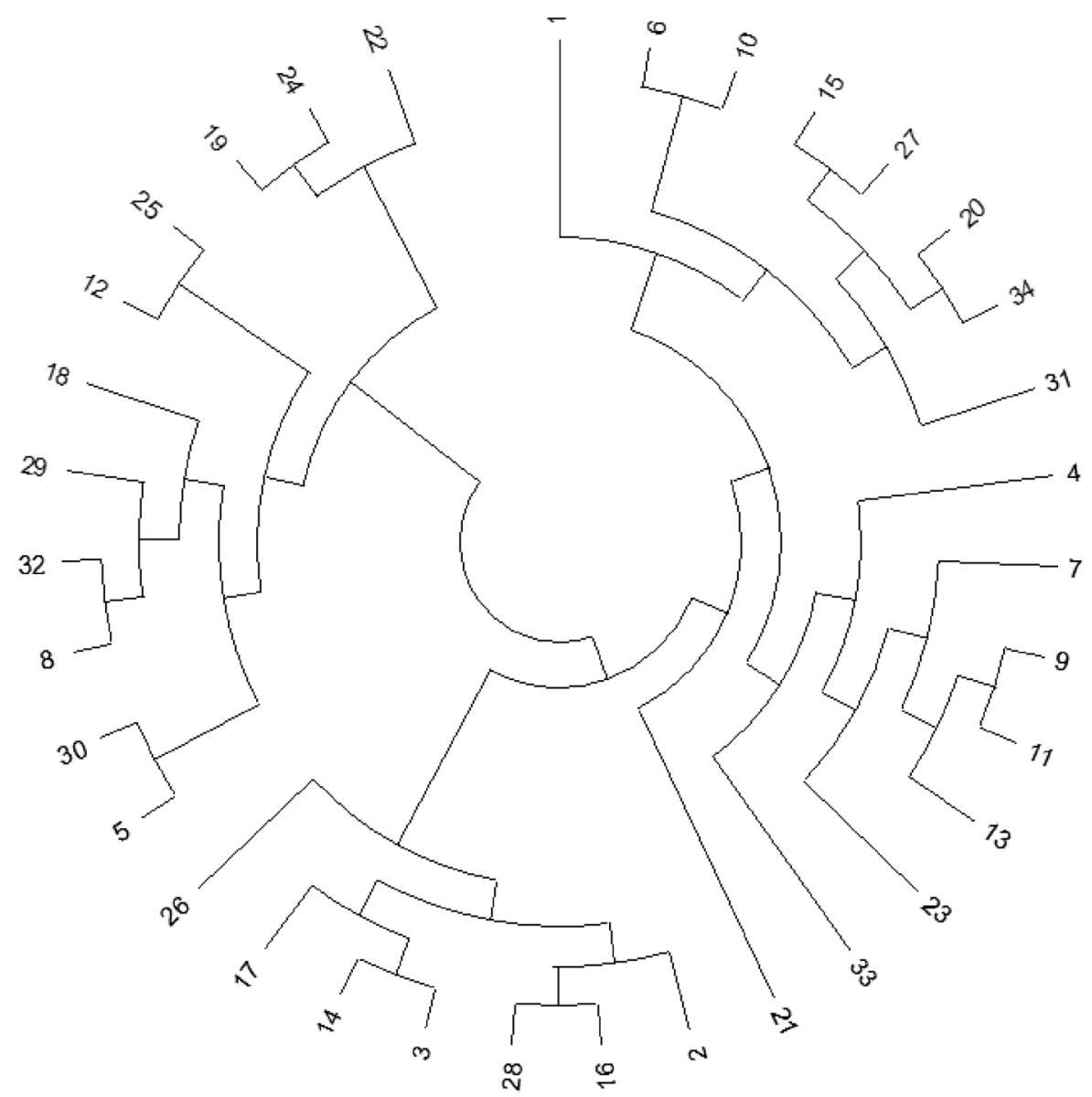

Fig. 1 Evolutionary 18S rRNA analysis of the 34 Babesia spp. isolates obtained from Dermacentor reticulatus ticks within the city of Białystok (see Table S1 for further details), inferred by using the maximum likelihood method and the Tamura-Nei model

2018). Noticeably higher prevalence was reported by Dzięgiel et al. (2014) (21.3\%) and Tomanovic et al. (2013) (20.8\%).

Babesia microti is considered to be the most common causative agent for human babesiosis (Vannier et al. 2008). Its primary tick vectors are Ixodes scapularis and I. ricinus (Vannier et al. 2008; Wójcik-Fatla et al. 2012). To date, limited data are available regarding the potential role of $D$. reticulatus as a vector for $B$. microti. Research conducted by Wójcik-Fatla et al. (2012) confirmed the presence of B. microti in $4.5 \%$ of tested ticks. As stressed by the authors, this was the first report on $B$. microti presence in adult $D$. reticulatus. In the present study, B. microti accounted for $0.8 \%$ of examined ticks and was also found only in adults. In other studies detected prevalence rate was 0.04-4.0\% (Mierzejewska et al. 2015; Opalińska et al. 2016; Zając et al. 2017). To the best of our knowledge, this is the first report of $B$. microti presence in questing adult $D$. reticulatus in urban surroundings. Although this tick rarely feeds on humans, presence of B. microti within the city is of epidemiological importance. 
In this study, one adult tick was infected with B. venatorum, which is another causative agent for human babesiosis (Hildebrandt et al. 2013). To date, only two other studies, from Lithuania and Russia, reported the presence of this pathogen in D. reticulatus. In both, $B$. venatorum was detected in a single tick (Livanova et al. 2018; Radzijevskaja et al. 2018).

Babesia vogeli is one of the causative agents of canine babesiosis. In Europe, this pathogen is commonly found in the Mediterranean area and transmitted by Rhipicephalus sanguineus, which is the predominant tick species there (René-Martellet et al. 2015). To date, no other research confirmed $B$. vogeli in $D$. reticulatus.

In the current study, $0.8 \%$ of $D$. reticulatus ticks was infected with A. phagocytophilum. In Poland, similarly low prevalence was reported in rural areas in the eastern region $(1.1 \%)$ (Zając et al. 2017), whereas in western provinces A. phagocytophilum was not detected in any of the tested D. reticulatus ticks (Opalińska et al. 2016). Prevalence of A. phagocytophilum was 0-1\% in the city of Kyiv, Ukraine (Didyk et al. 2017; Rogovskyy et al. 2018), $0 \%$ in Germany (Richter et al. 2013) and 1.9\% in rural areas of Serbia (Tomanovic et al. 2013).

In this study, the presence of $B$. afzelii was confirmed in only one D. reticulatus tick $(0.3 \%)$. Low prevalence has been reported by several other studies in Poland: $0.09 \%$ in Masovian Voivodeship (rural areas) (Mierzejewska et al. 2015) and 0.6-1.6\% in Lubelskie Voivodeship (rural areas) (Dzięgiel et al. 2014; Zając et al. 2017). Low prevalence was also reported for B. burgdorferi s.l. infection in D. reticulatus ticks, such as $2.0 \%$ in Wroclaw Agglomeration (urban areas) (Król et al. 2015), as well as in other European countries (studies in rural landscapes): $1.8 \%$ in Belarus (Reye et al. 2013) and 0\% in Serbia (Tomanovic et al. 2013) and Germany (Richter et al. 2013). A possible explanation for such low prevalence may be found in research conducted by Johns et al. (2001) who observed D. variabilis to be highly immunocompetent against Borrelia spirochetes. Rudolf et al. (2003) demonstrated the inhibition of Borrelia bacteria growth by extracts from the midguts of $D$. reticulatus (in vitro). Based on these findings, Dermacentor ticks appear ineffective vectors for $B$. burgdorferi s.l.

No $D$. reticulatus ticks examined in this study tested positive for presence of $C$. burnetii. Similar results were obtained by Tylewska-Wierzbanowska et al. (1996). Consistent values have been reported in rural areas in Germany and Belarus (Pluta et al. 2010; Reye et al. 2013), whereas in Slovakia studies show 0-2.1\% prevalence (Smetanová et al. 2006; Špitalská et al. 2018). In Serbia, Tomanovic et al. (2013) obtained 3.7\% C. burnetii infection rate. In comparison, Bonnet et al. (2013) confirmed the presence of C. burnetii in 16\% of $D$. reticulatus ticks collected in various rural locations in France.

Bartonella spp. was not detected in any of the D. reticulatus ticks tested in this study. This pathogen was found to be present in one D. reticulatus ( $0.5 \%$ of all examined ticks) collected from vegetation in an urban park in Warsaw, Poland (Podsiadly et al. 2009). Such low prevalence was also reported in studies from rural areas in Belarus $(0.6 \%)$ (Reye et al. 2013 ) and Serbia (0\%) (Tomanovic et al. 2013), as well as in the city of Kyiv, Ukraine (1.0\%) (Rogovskyy et al. 2018).

No $D$. reticulatus ticks tested positive for the presence of Rickettsia spp. This is especially surprising, giving that other research conducted in Podlaskie voivodeship reported 40.7-56.7\% prevalence, even though those studies were conducted in rural landscapes (Stańczak 2006; Chmielewski et al. 2009; Stańczak et al. 2018). High Rickettsia spp. infection rates (41.8-53.0\%) were reported from various regions of Poland (Wójcik-Fatla et al. 2013; Mierzejewska et al. 2015; Zając et al. 2017). Interestingly, prevalence reported in other European countries is not as high: 10.1-35.7\% in Ukraine (urban areas) (Didyk et al. 
2017; Rogovskyy et al. 2018), 14\% in The Netherlands (rural areas) (Nijhof et al. 2007) and $21.4 \%$ in Germany (rural areas) (Dautel et al. 2006).

In conclusion, results obtained in this study provide valuable information about prevalence of tick-borne pathogens in D. reticulatus ticks. Specimens were infected with at least three pathogens: B. burgdorferi s.l., A. phagocytophilum and Babesia spp. Additionally, this research provided the first identification of $B$. vogeli in $D$. reticulatus ticks. Therefore, further investigation is necessary in order to estimate the risk of human and animal infection.

Supplementary Information The online version contains supplementary material available at https://doi. org/10.1007/s10493-021-00655-x.

Author contributions Conceptualization: AM, SP, JD, AG; Methodology: JD, AG; Formal analysis and investigation: AG, JD; Writing — original draft preparation: AG; Writing — review and editing: AG, AM, PC, SP, JD, MW; Funding acquisition: AG; Evolutionary analysis: PM, ET; Supervision: AM, SP. All authors read and approved the final manuscript.

Funding This work was supported by Medical University of Bialystok [Grant number N/ST/ MN/18/001/1145]. MW has received funding from the European Union's Horizon 2020 research and innovation program under the Marie Sklodowska-Curie Grant Agreement No. 754432 and the Polish Ministry of Science and Higher Education, from financial resources for science in 2018-2023 granted for the implementation of an international co-financed project.

Data availability All data generated or analyzed during this study are included in this published article.

\section{Declarations}

Conflict of interests The authors declare that they have no conflict of interest.

Ethical approval All procedures performed in studies involving animals were in accordance with the ethical standards of the institution or practice at which the studies were conducted (Bioethics Committee, Medical University of Białystok; Permit number: R-I-002/341/2018).

Open Access This article is licensed under a Creative Commons Attribution 4.0 International License, which permits use, sharing, adaptation, distribution and reproduction in any medium or format, as long as you give appropriate credit to the original author(s) and the source, provide a link to the Creative Commons licence, and indicate if changes were made. The images or other third party material in this article are included in the article's Creative Commons licence, unless indicated otherwise in a credit line to the material. If material is not included in the article's Creative Commons licence and your intended use is not permitted by statutory regulation or exceeds the permitted use, you will need to obtain permission directly from the copyright holder. To view a copy of this licence, visit http://creativecommons.org/licenses/by/4.0/.

\section{References}

Akimov IA, Nebogatkin IV (2016) Ixodid ticks (Acari, Ixodidae) in urban landscapes. A review. Vestn Zool 50:155-162. https://doi.org/10.1515/vzoo-2016-0018

Bonnet S, De La Fuente J, Nicollet P et al (2013) Prevalence of tick-borne pathogens in adult Dermacentor spp. ticks from nine collection sites in France. Vector Borne Zoonotic Dis 13:226-236. https://doi.org/ 10.1089/vbz.2011.0933

Chmielewski T, Podsiadly E, Karbowiak G, Tylewska-Wierzbanowska S (2009) Rickettsia spp. in ticks, Poland. Emerg Infect Dis 15:486-488. https://doi.org/10.3201/eid1503.080711 
Dautel H, Dippel C, Oehme R et al (2006) Evidence for an increased geographical distribution of Dermacentor reticulatus in Germany and detection of Rickettsia sp. RpA4. Int J Med Microbiol 296:149-156. https:// doi.org/10.1016/j.ijmm.2006.01.013

Didyk YM, Blaňárová L, Pogrebnyak S et al (2017) Emergence of tick-borne pathogens (Borrelia burgdorferi sensu lato, Anaplasma phagocytophilum, Rickettsia raoultii and Babesia microti) in the Kyiv urban parks, Ukraine. Ticks Tick Borne Dis 8:219-225. https://doi.org/10.1016/j.ttbdis.2016.10.002

Dunaj J, Moniuszko-Malinowska A, Swiecicka I et al (2018) Tick-borne infections and co-infections in patients with non-specific symptoms in Poland. Adv Med Sci 63:167-172. https://doi.org/10.1016/j.advms.2017. 09.004

Dzięgiel B, Kubrak T, Adaszek $€$ et al (2014) Prevalence of Babesia canis, Borrelia burgdorferi sensu lato, and Anaplasma phagocytophilum in hard ticks collected from meadows of Lubelskie Voivodship (eastern Poland). Bull Vet Inst Pulawy 58:29-33. https://doi.org/10.2478/bvip-2014-0005

Földvári G, Široký P, Szekeres S et al (2016) Dermacentor reticulatus: a vector on the rise. Parasit Vectors 9:1-29. https://doi.org/10.1186/s13071-016-1599-X

Hildebrandt A, Gray JS, Hunfeld KP (2013) Human Babesiosis in Europe: what clinicians need to know. Infection 41:1057-1072. https://doi.org/10.1007/s15010-013-0526-8

Johns R, Ohnishi J, Broadwater A et al (2001) Contrasts in tick innate immune responses to Borrelia burgdorferi challenge: immunotolerance in Ixodes scapularis versus immunocompetence in Dermacentor variabilis (Acari: Ixodidae). J Med Entomol 38:99-107. https://doi.org/10.1603/0022-2585-38.1.99

Katargina O, Geller J, Vasilenko V et al (2011) Detection and characterization of Babesia species in Ixodes ticks in Estonia. Vector Borne Zoonotic Dis 11:923-928. https://doi.org/10.1089/vbz.2010.0199

Król N, Kiewra D, Szymanowski M, Lonc E (2015) The role of domestic dogs and cats in the zoonotic cycles of ticks and pathogens. Preliminary studies in the Wroclaw Agglomeration (SW Poland). Vet Parasitol 214:208-212. https://doi.org/10.1016/j.vetpar.2015.09.028

Kumar S, Stecher G, Li M et al (2018) MEGA X: molecular evolutionary genetics analysis across computing platforms. Mol Biol Evol 35:1547-1549. https://doi.org/10.1093/molbev/msy096

Livanova NN, Fomenko NV, Akimov IA et al (2018) Dog survey in Russian veterinary hospitals: tick identification and molecular detection of tick-borne pathogens. Parasit Vectors 11:1-10. https://doi.org/10.1186/ s13071-018-3161-5

Mierzejewska EJ, Pawełczyk A, Radkowski M et al (2015) Pathogens vectored by the tick, Dermacentor reticulatus, in endemic regions and zones of expansion in Poland. Parasit Vectors. https://doi.org/10.1186/ s13071-015-1099-4

Moniuszko A, Dunaj J, Święcicka I et al (2014) Co-infections with Borrelia species, Anaplasma phagocytophilum and Babesia spp. in patients with tick-borne encephalitis. Eur J Clin Microbiol Infect Dis 33:18351841. https://doi.org/10.1007/s10096-014-2134-7

Moniuszko-Malinowska A, Swiecicka I, Dunaj J et al (2016) Infection with Babesia microti in humans with non-specific symptoms in North East Poland. Infect Dis (auckl) 48:537-543. https://doi.org/10.3109/ 23744235.2016.1164339

Nijhof AM, Bodaan C, Postigo M et al (2007) Ticks and associated pathogens collected from domestic animals in the Netherlands. Vector Borne Zoonotic Dis 7:585-595. https://doi.org/10.1089/vbz.2007.0130

Nowak-Chmura M (2013) Fauna kleszczy (Ixodida) Europy Środkowej. Wydawnictwo Naukowe Uniwersytetu Pedagogicznego, Kraków

Opalińska P, Wierzbicka A, Asman M (2016) The PCR and nested PCR detection of Borrelia burgdorferi sensu lato, Anaplasma phagocytophilum and Babesia microti in Dermacentor reticulatus collected in a new location in Poland (Trzciel, Western Poland). Acta Parasitol 61:849-854. https://doi.org/10.1515/ ap-2016-0117

Piccolin G, Benedetti G, Doglioni C et al (2006) A study of the presence of B. burgdorferi, Anaplasma (previously Ehrlichia) phagocytophilum, Rickettsia, and Babesia in Ixodes ricinus collected within the territory of Belluno, Italy. Vector Borne Zoonotic Dis 6:24-31. https://doi.org/10.1089/vbz.2006.6.24

Pichon B, Kahl O, Hammer B, Gray JS (2006) Pathogens and host DNA in Ixodes ricinus nymphal ticks from a German forest. Vector Borne Zoonotic Dis 6:382-387. https://doi.org/10.1089/vbz.2006.6.382

Pluta S, Hartelt K, Oehme R et al (2010) Prevalence of Coxiella burnetii and Rickettsia spp. in ticks and rodents in southern Germany. Ticks Tick Borne Dis 1:145-147. https://doi.org/10.1016/j.ttbdis.2010.04.001

Podsiadly E, Karbowiak G, Tylewska-Wierzbanowska S (2009) Presence of Bartonella spp. in Ixodidae ticks. Clin Microbiol Infect 15:120-121. https://doi.org/10.1111/j.1469-0691.2008.02196.x

Radzijevskaja J, Mardosaite-Busaitiene D, Aleksandraviciene A, Paulauskas A (2018) Investigation of Babesia spp. in sympatric populations of Dermacentor reticulatus and Ixodes ricinus ticks in Lithuania and Latvia. Ticks Tick Borne Dis 9:270-274. https://doi.org/10.1016/j.ttbdis.2017.09.013

René-Martellet M, Moro CV, Chêne J et al (2015) Update on epidemiology of canine babesiosis in Southern France. BMC Vet Res 11:1-11. https://doi.org/10.1186/s12917-015-0525-3 
Reye AL, Stegniy V, Mishaeva NP et al (2013) Prevalence of tick-borne pathogens in Ixodes ricinus and Dermacentor reticulatus ticks from different geographical locations in Belarus. PLoS ONE 8:14-16. https:// doi.org/10.1371/journal.pone.0054476

Richter D, Kohn C, Matuschka F-R (2013) Absence of Borrelia spp., Candidatus Neoehrlichia mikurensis, and Anaplasma phagocytophilum in questing adult Dermacentor reticulatus ticks. Parasitol Res 112:107-111. https://doi.org/10.1007/s00436-012-3110-8

Rizzoli A, Silaghi C, Obiegala A et al (2014) Ixodes ricinus and its transmitted pathogens in urban and periurban areas in Europe: new hazards and relevance for public health. Front Public Heal 2:1-26. https://doi. org/10.3389/fpubh.2014.00251

Roczeń-Karczmarz M, Dudko P, Demkowska-Kutrzepa M et al (2018) Comparison of the occurrence of tickborne diseases in ticks collected from vegetation and animals in the same area. Med Weter 74:484-488. https://doi.org/10.21521/mw.6107

Rogovskyy A, Batool M, Gillis DC et al (2018) Diversity of Borrelia spirochetes and other zoonotic agents in ticks from Kyiv, Ukraine. Ticks Tick Borne Dis 9:404-409. https://doi.org/10.1016/j.ttbdis.2017.12.006

Rudolf I, Hubalek Z (2003) Effect of the salivary gland and midgut extracts from Ixodes ricinus and Dermacentor reticulatus (Acari: Ixodidae) on the growth of Borrelia garinii in vitro. Folia Parasitol (praha) 50:159-160

Silaghi C, Woll D, Hamel D et al (2012) Babesia spp. and Anaplasma phagocytophilum in questing ticks, ticks parasitizing rodents and the parasitized rodents - analyzing the host-pathogen-vector interface in a metropolitan area. Parasit Vectors 5:1-14. https://doi.org/10.1186/1756-3305-5-191

Silaghi C, Weis L, Pfister K (2020) Dermacentor reticulatus and babesia canis in bavaria (Germany)—a georeferenced field study with digital habitat characterization. Pathogens 9:1-10. https://doi.org/10.3390/patho gens 9070541

Šimo L, Kocáková P, Sláviková M et al (2004) Dermacentor reticulatus (Acari, Ixodidae) female feeding in laboratory. Biol Sect Zool 59:655-660

Smetanová K, Schwarzová K, Kocianová E (2006) Detection of Anaplasma phagocytophilum, Coxiella burnetii, Rickettsia spp., and Borrelia burgdorferi s. 1. in ticks, and wild-living animals in Western and Middle Slovakia. Ann N Y Acad Sci 1078:312-315. https://doi.org/10.1196/annals.1374.058

Špitalská E, Sparagano O, Stanko M et al (2018) Diversity of Coxiella-like and Francisella-like endosymbionts, and Rickettsia spp., Coxiella burnetii as pathogens in the tick populations of Slovakia, Central Europe. Ticks Tick Borne Dis 9:1207-1211. https://doi.org/10.1016/j.ttbdis.2018.05.002

Sprong H, Fonville M, Docters van Leeuwen A et al (2019) Detection of pathogens in Dermacentor reticulatus in northwestern Europe: evaluation of a high-throughput array. Heliyon. https://doi.org/10.1016/j.heliyon. 2019.e01270

Stańczak J (2006) Detection of spotted fever group (SFG) rickettsiae in Dermacentor reticulatus (Acari: Ixodidae) in Poland. Int J Med Microbiol 296:144-148. https://doi.org/10.1016/j.ijmm.2006.01.014

Stańczak J, Biernat B, Racewicz M et al (2018) Prevalence of different Rickettsia spp. in Ixodes ricinus and Dermacentor reticulatus ticks (Acari: Ixodidae) in north-eastern Poland. Ticks Tick Borne Dis 9:427-434. https://doi.org/10.1016/j.ttbdis.2017.12.010

Tamura K, Nei M (1993) Estimation of the number of nucleotide substitutions in the control region of mitochondrial DNA in humans and chimpanzees. Mol Biol Evol 10:512-526. https://doi.org/10.1093/oxfor djournals.molbev.a040023

Tomanovic S, Chochlakis D, Radulovic Z et al (2013) Analysis of pathogen co-occurrence in host-seeking adult hard ticks from Serbia. Exp Appl Acarol 59:367-376. https://doi.org/10.1007/s10493-012-9597-y

Tylewska-Wierzbanowska S, Kruszewska D, Chmielewski T et al (1996) Ticks as a reservoir of Borrelia burgdorferi and Coxiella burnetii on Polish terrain. Przegl Epidemiol 50:245-251

Vannier E, Gewurz BE, Krause PJ (2008) Human babesiosis. Infect Dis Clin North Am 22:469-488. https://doi. org/10.1016/j.idc.2008.03.010

Wójcik-Fatla A, Bartosik K, Buczek A, Dutkiewicz J (2012) Babesia microti in adult Dermacentor reticulatus ticks from eastern Poland. Vector Borne Zoonotic Dis 12:841-843. https://doi.org/10.1089/vbz.2011.0904

Wójcik-Fatla A, Cisak E, Zajac V et al (2013) Study on tick-borne rickettsiae in eastern Poland. I. Prevalence in Dermacentor reticulatus (Acari: Amblyommidae). Ann Agric Environ Med 20:276-279

Zając V, Wójcik-Fatla A, Sawczyn A et al (2017) Prevalence of infections and co-infections with six pathogens in Dermacentor reticulatus ticks collected in eastern Poland. Ann Agric Environ Med 24:26-32. https:// doi.org/10.5604/12321966.1233893

Publisher's Note Springer Nature remains neutral with regard to jurisdictional claims in published maps and institutional affiliations. 